\title{
Third ventricle arachnoid cyst presenting with acute hydrocephalus: A case report and review of the literature
}

\section{Akut hidrosefali ile gelen üçüncü ventrikül araknoid kisti: Olgu sunumu ve literatür taraması}

Elif AKPINAR ${ }^{1} \oplus$, Mehmet Sabri GÜRBÜZ $Z^{2} \oplus$, Mehmet Özerk OKUTAN ${ }^{1} \odot$, Ethem BEŞKONAKLI ${ }^{\circledR}$

ABSTRACT

We present a 57-year-old male admitted to emergency department with acute loss of consciousness and diagnosed with third ventricular arachnoid cyst. Transcallosal cyst resection was performed following an emergency ventriculostomy. Postoperative imaging revealed gross-total cyst excision and a moderate decrease in hydrocephalus. However, the patient improved only after a subsequent ventriculoperitoneal shunting. This time, however, a subdural hematoma occurred under the craniotomy incision. In conclusion, surgical approach for the treatment of arachnoid cysts of the third ventricle should be selected carefully. Cyst excision via open craniotomy may require subsequent shunting and can cause serious complications such as subdural hematoma.

Keywords: Arachnoid cyst, third ventricle, hydrocephalus, craniotomy, shunt, complication
Öz

Acile ani şuur kaybı ile gelen ve üçüncü ventrikül araknoid kisti belirlenen 57 yaşında bir erkek hasta sunuyoruz. Hastaya acil ventrikülostomi sonrası transkallozal kist rezeksiyonu uygulandı. Postoperatif görüntülemede kistin gros-total eksize edildiği ve hidrosefalide orta derecede azalma olduğu görüldü. Hastanın durumunda ancak vetriküloperitoneal şant takıldıktan sonra düzelme görüldü. Ancak bu kez de kraniotominin altında subdural hematom oluştu. Sonuçta, üçüncü ventrikül araknoid kistlerinin cerrahi tedavisinde yeğlenecek yaklaşım dikkatle seçilmelidir. Açık kraniyotomi ile kist eksizyonunda şant gereksinimi olabilir ve bu yaklaşım subdural hematom gibi ciddi komplikasyonlara neden olabilir.

Anahtar kelimeler: Araknoid kist, üçücü ventrikül, kraniyotomi, şant, komplikasyon

\section{INTRODUCTION}

The prevalence of arachnoid cysts is $1.4 \%$ in adults ${ }^{1}$. Ventricular arachnoid cysts are very rare, because there is no arachnoid tissue in the ventricles. Third ventricle arachnoid cysts are even rarer and to our knowledge, only 7 cases have been reported in the literature so far.

Since there are few published cases of third ventricular arachnoid cysts, the optimal surgical strategy remains controversial. Open craniotomy, endoscopic approaches, CSF diversion and their combinations are the techniques used in the literature. Here we report a 57-year-old male admitted to emergency department with acute loss of consciousness and diagnosed with third ventricular arachnoid cyst. Treatment strategy is discussed and the previously published cases are reviewed accordingly.

\section{CASE REPORT}

A 57-year-old male was admitted to the emergency department with sudden loss of consciousness. His

Received: ???

Accepted: 22.12.2017

${ }^{1}$ Karatay University Medical Faculty, Medicana Hospital, Department of Neurosurgery, Konya, Turkey

${ }^{2}$ Istanbul Medeniyet University, Medical School, Department of Neurosurgery, İstanbul, Turkey

${ }^{3}$ Liv Hospital, Department of Neurosurgery, Ankara, Turkey

Yazışma adresi: Mehmet Sabri Gürbüz, İstanbul Medeniyet University, Medical School, Department of Neurosurgery, İstanbul, Turkey

e-mail: mehmetsabrigurbuz@gmail.com

Yazarların ORCiD bilgileri:

E.A. 0000-0001-5705-2870, M.S.G. 0000-0002-3764-389X, M.Ö.O. 0000-0002-0418-9395, E.B. 0000-0002-2903-5106 
medical history was unremarkable other than an intermittent headache lasting for 5 years. He had a Glasgow coma score (GCS) of 8 with normal pupillary examination. Cranial Computed Tomography (CT) revealed the presence of an acute hydrocephalus [Figure 1a]. Cranial Magnetic Resonance Imaging (MRI) demonstrated that the hydrocephalus was caused by third ventricular arachnoid cyst [Figure $1 b-c]$. Immedi- ately after the diagnosis, an external ventricular drainage system was inserted. The day after the ventriculostomy, surgical removal of the cyst was aimed via a right frontal craniotomy using transcallosal approach. Postoperative $\mathrm{CT}$ of the patient revealed a gross-total removal of the cyst with a moderate decrease in the ventricle sizes [Figure 2]. Histopathological diagnosis confirmed the presence of an arachnoid cyst. Howe-
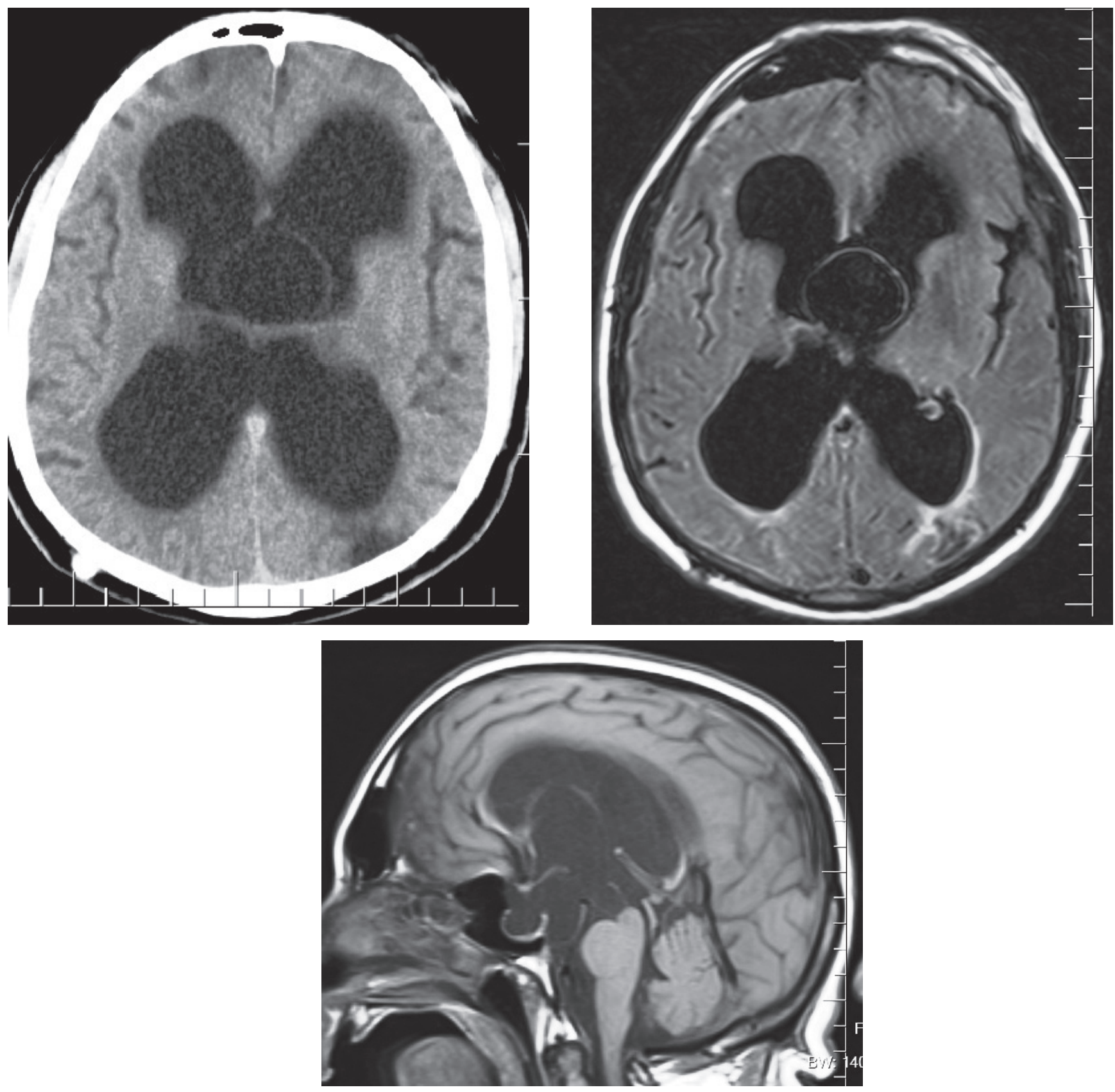

Figure 1. Preoperative cranial axial CT scan (a), preoperative cranial axial (b) and T-1 weighted sagittal (c) MRI scans demonstrating third ventricle arachnoid cyst and hydrocephalus. 


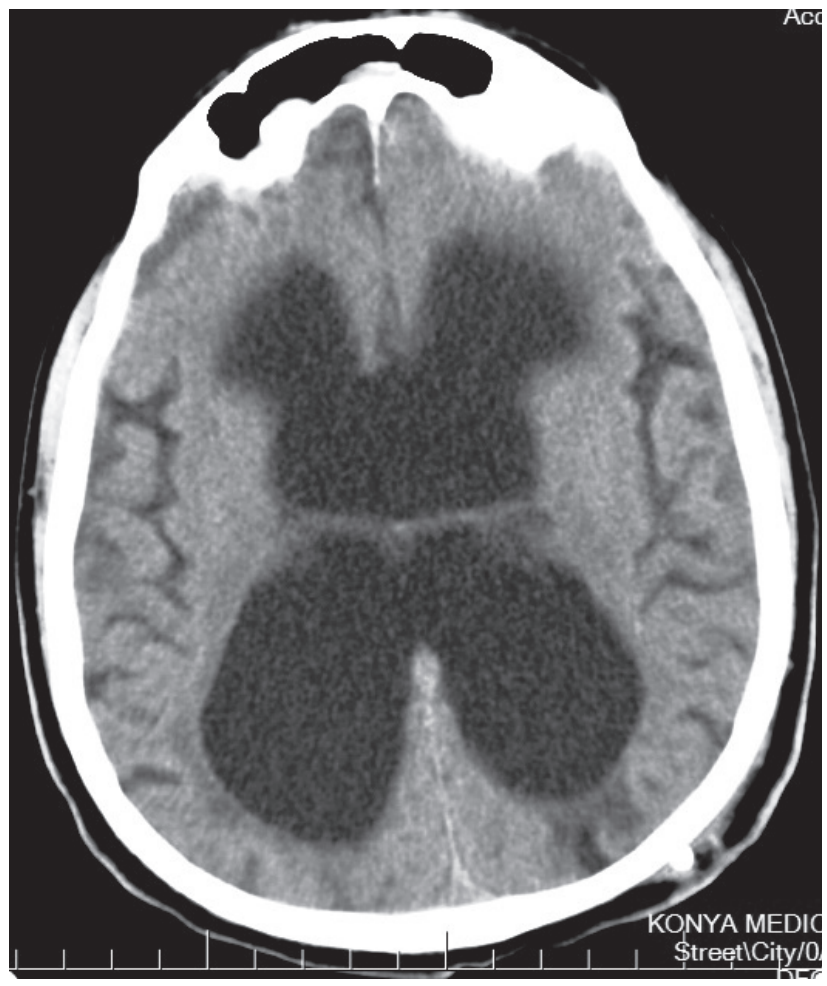

Figure 2. Postoperative cranial axial CT scan revealing a moderate decrease in ventricle sizes and a gross-total excision of arachnoid cyst.

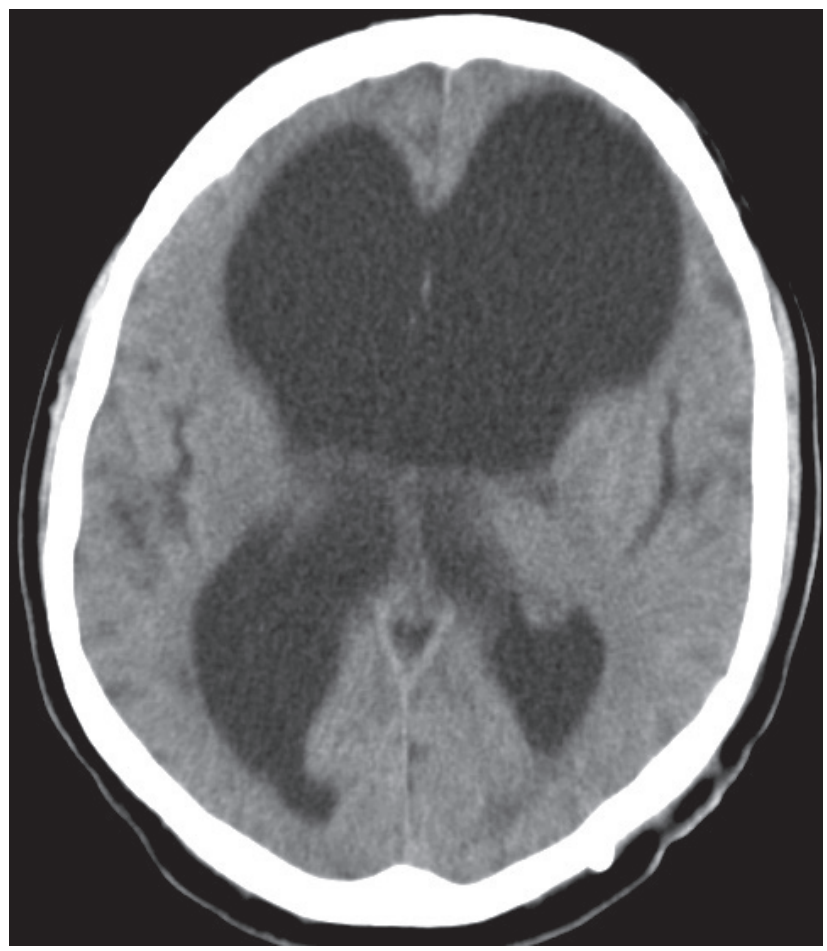

Figure 4. Cranial CT showing spontaneous resolution of subdural hematoma and over dilated frontal horns.

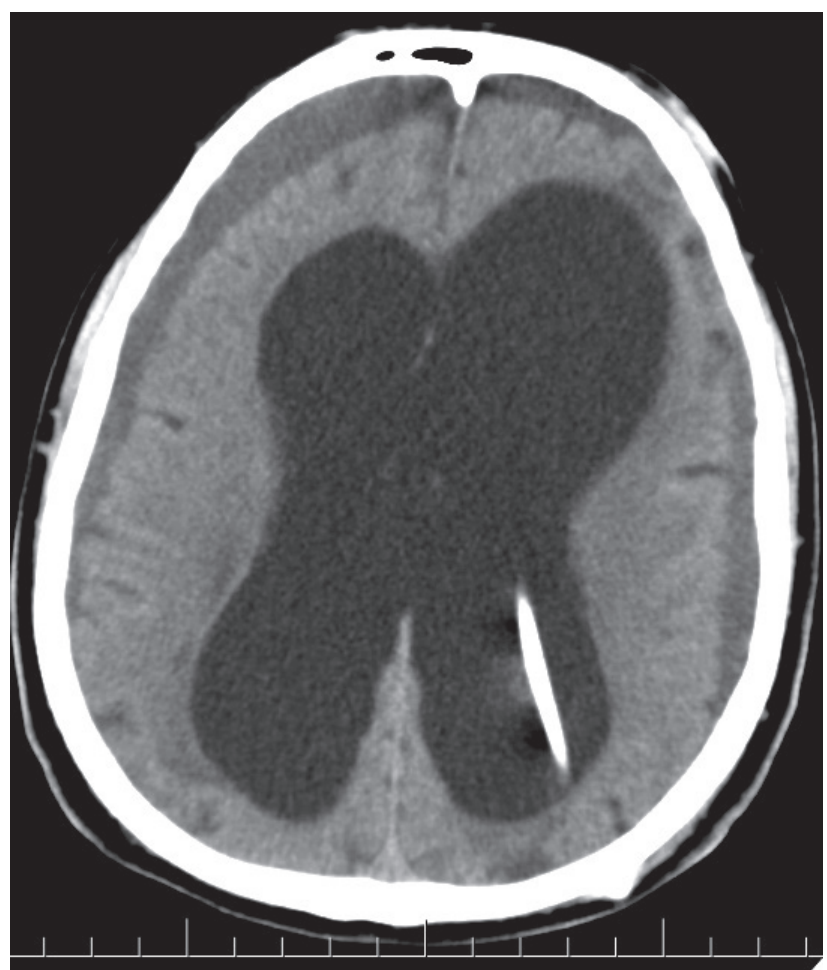

Figure 3. Postoperative cranial axial CT scan taken after ventriculoperitoneal shunting reveals bilateral frontoparietal subdural hematoma -the larger one being under the craniotomy on the right side- and the shunt catheter inserted from the left Frazier point.

ver, hydrocephalus still existed, and the patient's GCS did not improve alongside these radiological findings. A medium pressure ventriculoperitoneal shunt was inserted from left Frazier point and the GCS of the patient improved immediately after the placement of ventriculoperitoneal shunt. This time, however, bilateral frontoparietal subdural hematoma -the larger one being under the craniotomy on the right sidewas observed under the craniotomy incision [Figure 3]. After a week of close observation, hematoma resolved spontaneously [Figure 4] and the patient was discharged from hospital with a GCS of 14.

\section{DISCUSSION}

Many arachnoid cysts remain asymptomatic but third ventricular arachnoid cysts can cause obstructive hydrocephalus as a result of either compression to the cerebral aqueduct or occlusion of foramen of Monro. There is some controversy over the ideal operative treatment of arachnoid cysts ${ }^{2,3}$. Since there 
are few published cases of third ventricular arachnoid cysts and different techniques have been used, the optimal surgical strategy for third ventricular arachnoid cysts remains controversial.

Hoffman et al. ${ }^{4}$ recommended a transcallosal approach based on the fact that this approach allows creation of a communication between the cyst and the ventricles. While transcallosal approach via craniotomy can achieve cyst fenestration and/or resection, an open approach might also result in damage to the crucial structures including vascular injury, disconnection syndromes, forniceal injury and damage to the subcortical nuclei ${ }^{5}$. On the other hand, Ciricillo et al. ${ }^{2}$ reported that $67 \%$ of the patients with intracranial arachnoid cysts operated via craniotomy required subsequent cyst shunting, while Raffel et al. ${ }^{3}$ reported that $76 \%$ of the patients treated by craniotomy and fenestration did not require further shunting.

Ventriculoperitoneal shunting is effective for the treatment of hydrocephalus associated with arachnoid cysts; however, these shunts often require further revisions ${ }^{2,3}$. However it should be noted that, shunting the cyst itself-which is technically difficult, is different than shunting for the hydrocephalus associated with cyst. Despite all these known risks, ventriculoperitoneal shunts are useful and sometimes inevitable when hydrocephalus and its clinical findings persist following cyst resection or fenestration. The indications for revisions depend on the patient's clinical condition rather than the postoperative radiological imaging. Kirollos et al. ${ }^{6}$ reported that none of their patients had total collapse of the cyst following surgery. They claimed that satisfactory clinical improvement can be achieved even with moderate or slight reduction of cyst volume.

In our case, patient's GCS did not improve after the surgery despite reduction of the cyst size and moderate decrease in hydrocephalus. Therefore, a ventriculoperitoneal shunt was placed which provided an improvement of GCS immediately after the procedure. However, shunting resulted in subdural hematoma possibly because of rapid decompression. Although hematoma resolved spontaneously in a week, the patient was discharged with a GCS of 14 .

Cyst fenestration or resection via craniotomy has potential risks of complications such as neurological deficits, meningitis, subdural collections, and epileptic convulsions ${ }^{3}$. As a result, endoscopic approaches have become popular recently in many areas as well as for the treatment of arachnoid cysts, since thay are less invasiveness and help avoid complications related to shunting ${ }^{6,7}$. Kirollos et al. ${ }^{6}$ claimed that endoscopic approach helps avoid the complications related to shifts of the intracranial structures resulting from rapid decompression. Endoscope allows the surgeon to perform an additional third ventriculostomy and also gives the chance of fenestrating the cyst to the ventricles and the basal cisterns.

Faris et al. ${ }^{8}$, Ericson et al. ${ }^{9}$, and Tamburus et al. ${ }^{10}$ used stereotactic puncture, craniotomy and craniotomy with additional shunting respectively, between the years 1971 and 1987 when endoscopic techniques were not popular. In 2010, -after introduction of endoscope, Shiba et al. ${ }^{11}$ reported that they established a communication between the third ventricle, arachnoid cyst and aqueduct of Sylvius via endoscopic approach and then performed endoscopic third ventriculostomy in the same session. They reported a good outcome at one-year follow-up. In 2014, Jeltema et al. ${ }^{12}$ reported that they performed endoscopic fenestration, partial cyst removal using endoscopic instruments and ventriculocisternostomy with a successful result. In 2015, Ho et al. ${ }^{7}$ described simultaneous endoscopic cyst fenestration and endoscopic third ventriculostomy via double burr-hole using separate trajectories to avoid forniceal injury. They recommended this technique particularly in multilocular cysts so as to avoid further revision fenestrations and permanent shunting. Reviewing the published cases of third ventricle arachnoid cyst in a chronological order (Table 1), a recent trend toward using endoscopic approaches is worth noting.

\section{CONCLUSION}

Surgical strategy for the treatment of arachnoid cysts of the third ventricle should be selected carefully. 
Table 1. Cases of third ventricular arachnoid cyst.

\begin{tabular}{|c|c|c|c|c|}
\hline Author/ Year & Age/Sex & Signs and Symptoms & Radiological findings & Operative technique \\
\hline Faris et al. (10) 1971 & $16 / \mathrm{M}$ & Headache, precocious puberty & Triventricular hydrocephalus & $\begin{array}{l}\text { Frontal craniotomy and } \\
\text { fenestration }\end{array}$ \\
\hline Ericson et al. (11) 1986 & $5 / \mathrm{M}$ & $\begin{array}{l}\text { Headache, nausea, } \\
\text { somnolence }\end{array}$ & Slightly enlarged third ventricle & Stereotactic puncture \\
\hline Tamburus et al. (12) 1987 & $20 / \mathrm{M}$ & $\begin{array}{l}\text { Neausea, vomiting, horizontal } \\
\text { nystagmus }\end{array}$ & Triventricular hydrocephalus & $\begin{array}{l}\text { Ommaya reservoir, parietal } \\
\text { craniotomy, cyst excision }\end{array}$ \\
\hline Tamburus et al. (12) 1987 & $46 / \mathrm{M}$ & $\begin{array}{l}\text { Intracranial hypertension, } \\
\text { optic atrophy }\end{array}$ & Aqueductal stenosis & $\begin{array}{l}\text { Ventricular drainage, VA shunt, } \\
\text { frontoparietal craniotomy and } \\
\text { fenestration }\end{array}$ \\
\hline Shiba et al. (8) 2010 & $35 / M$ & Epilepsy, mental retardation & Triventricular hydrocephalus & $\begin{array}{l}\text { Endoscopic fenestration and } \\
\text { ETV }\end{array}$ \\
\hline Jeltema et al. (9) 2014 & $2.5 /-$ & Altered consciousness & Triventricular hydrocephalus & $\begin{array}{l}\text { Endoscopic fenestration, } \\
\text { partial cyst removal } \\
\text { ventriculocisternostomy } \\
\text { endoscopic fenestration, ETV }\end{array}$ \\
\hline Ho et al. (7) 2015 & $33 / F$ & $\begin{array}{l}\text { Headache, blurred vision, } \\
\text { galactorrhea }\end{array}$ & $\begin{array}{l}\text { Hydrocephalus with slightly } \\
\text { enlarged third ventricle }\end{array}$ & $\begin{array}{l}\text { Frontal craniotomy, gross-total } \\
\text { cyst excision }\end{array}$ \\
\hline Present case & $57 / M$ & loss of consciousness & Triventricular hydrocephalus & VP shunt \\
\hline
\end{tabular}

Cyst excision via craniotomy might not be desirable, due to the possibility of requiring additional shunting and associated complications such as subdural hematoma. Endoscopic approaches might be considered owing to their being less invasive and giving a further chance of endoscopic third ventriculostomy.

\section{REFERENCES}

1. Al-Holou WN, Terman S, Kilburg C, Garton HJ, Muraszko KM, Maher CO. Prevalence and natural history of arachnoid cysts in adults. J Neurosurg. 2013;118(2):222-31. https://doi.org/10.3171/2012.10.JNS12548

2. Ciricillo SF, Cogen PH, Harsh GR, Edwards MSB. Intracranial arachnoid cysts in children. A comparison of the effects of fenestration and shunting. J Neurosurg. 1991;74:230-5. https://doi.org/10.3171/jns.1991.74.2.0230

3. Raffel C, McComb JG. To shunt or to fenestrate: which is the best surgical treatment for arachnoid cysts in pediatric patients? Neurosurgery. 1988;23:338-42. https://doi.org/10.1227/00006123-198809000-00009

4. Hoffman HJ, Hendrick EB, Humphreys RP, Armstrong EA. Investigation and management of suprasellar arachnoid cysts. J Neurosurg. 1982;57:597-602. https://doi.org/10.3171/jns.1982.57.5.0597

5. Lewis Al, Keiper GL, Jr., Crone KR. Endoscopic treatment of loculated hydrocephalus. J Neurosurg. 1995;82:780-5. https://doi.org/10.3171/jns.1995.82.5.0780
6. Kirollos RW, Javadpour M, May P, Mallucci C. Endoscopic treatment of suprasellar and third ventricle-related arachnoid cysts. Childs Nerv Syst. 2001;17(12):713-8. https://doi.org/10.1007/s003810100494

7. Ho AL, Pendharkar AV, Sussman ES, Ravikumar VK, Li GH. Dual-trajectory Approach for Simultaneous Cyst Fenestration and Endoscopic Third Ventriculostomy for Treatment of a Complex Third Ventricular Arachnoid Cyst. Cureus. 2015;7(3):e253.

https://doi.org/10.7759/cureus.253

8. Faris AA, Bale GF, Cannon B. Arachnoidal cyst of the third ventricle with precocious puberty. South Med J. 1971;64(9):113942.

https://doi.org/10.1097/00007611-197109000-00023

9. Ericson K, Lindqvist $M$, Norén $G$, Håkansson S. Mobile intraventricular cyst of the third ventricle treated with stereotactic puncture. Report of a case. Acta Radiol Diagn (Stockh). 1986;27(5):501-3. https://doi.org/10.1177/028418518602700503

10. Tamburus WM, Brock M, Wolter M. Arachnoid cyst of the $3 \mathrm{~d}$ ventricle: report of 2 cases. Arq Neuropsiquiatr 1987;45(3):295-301. https://doi.org/10.1590/S0004-282X1987000300010

11. Shiba M, Muramatsu M, Tanaka K, Hori K, Hatazaki S, Taki W. Acquired intraventricular arachnoid cyst of the third ventricle: case report. Neurol Med Chir (Tokyo). 2010;50(6):509-12. https://doi.org/10.2176/nmc.50.509

12. Jeltema HR, Kuijlen JM, Hoving EW. Acute hydrocephalus in a child with a third ventricle arachnoid cyst and coincidental enteroviral meningitis. Childs Nerv Syst. 2014;30(6):1129-33. https://doi.org/10.1007/s00381-013-2299-x 